\title{
When successful conservation breeds conflict: an economic perspective on wild goose management
}

\author{
DOUGLAS C. MACMILLAN and NIGEL LEADER-WILLIAMS
}

\begin{abstract}
Summary
Wild bird conservation in the UK is a widely regarded as a success story. The populations of many endangered species have grown or at least stabilised, birds that were last seen in the UK over 100 years ago have been successfully re-introduced, and bird watching makes an increasingly important contribution to the rural economy in terms of employment and income. Nevertheless, some wild birds also generate costs and some deep rooted conflicts persist with other rural activities such as farming and game shooting. This paper describes a conceptual framework for understanding the costs and benefits of wild birds and, using wild goose conservation in the island of Islay as a case study, explores whether continued public investment in wild goose conservation is worthwhile from an economic perspective. The paper concludes with a discussion about future options for integrating wild bird conservation with sustainable rural development.
\end{abstract}

\section{Introduction}

Wild birds are highly valued by society. In many places of the world, wild birds are an important resource for subsistence and trade, providing food, clothing, fuel, fertiliser, medicines, as well as resources of cultural and ceremonial significance. In industrial and post-industrial societies, wild birds contribute to our well-being in new and significant ways, and are increasingly valued in terms of recreational activities such as sport shooting and bird watching.

Although wild bird conservation in the UK is widely regarded as a success story, with the populations of many endangered species growing and other bird species last seen in the UK over IOO years ago now successfully re-introduced, there are situations where success has bred conflict. These conflicts are intensified by the nature and distribution of the costs and benefits of bird conservation: costs often fall on a relatively small group of people, and can directly affect household income and employment in rural areas, whereas the benefits are more intangible and accrue to urban households (Balmford and Whitten 2003). In the UK for example, illegal persecution of protected raptor species which prey on Red Grouse (Lagopus lagopus) has brought conservationists into direct conflict with landowners and more especially, their employees who fear for their livelihood (Thirgood and Redpath 2005)

If conservation is to play an integrated and sustainable role in the rural economy, such winlose situations must be avoided. In many parts of the world the responsibility for wildlife conflict resolution falls on the state, with the cost of compensation, out-reach programmes, and law enforcement typically met by the tax-payer (Nyhus et al. 2005). In order to understand and design policy to ensure that conservation objectives represent value-for-money, it is important to understand and quantify who bears the costs and who receives the benefits, their magnitude and how they manifest themselves, and how they are distributed spatially and temporally. For 
this reason economists, armed with new methodologies for valuing costs and benefits of wildlife have been taking an increasing interest in the design and effectiveness of conservation policy (DEFRA 2005, Phillip and MacMillan 2005, Hanley et al. 2003).

This paper brings an economic perspective to contemporary thinking about the economic costs and benefits of wild birds, and using wild goose conservation as a case study, shows how economic information costs and benefits can be used to help design policies to mitigate conflict over conservation. In the next section we introduce and explain the Total Economic Value framework for analysing the cost and benefits of bird conservation. We then describe a recent study to value the costs and benefits of conserving endangered wild goose populations in Scotland. Finally, the paper concludes with some thoughts on how conservation policy that has achieved its primary conservation objective might evolve to contribute to an integrated sustainable development strategy for rural areas.

\section{Total economic value of wild birds}

Wild birds generate a range of values to society. Economists have developed a conceptual framework, referred to as 'Total Economic Value', for understanding, compiling, and measuring these values. The framework encompasses both use and non-use values. Use values can be divided into consumptive and non-consumptive uses (Table 1 ).

Benefits are positive values that can be generated by either consumptive or non-consumptive activities. Consumptive benefits typically involve killing birds for food, clothing, recreational hunting or cultural purposes. Consumptive costs are negative values that can be generated by wild birds as a result of damage or loss to other consumable resources. For example, the predation of game birds, poultry and lambs by raptors, or crop losses due to grazing and trampling by geese. Non-consumptive benefits include the enjoyment of watching wild birds in situ or on TV, while non-consumptive costs include the fear of birds (ornithophobia).

Bird conservation can also generate a range of indirect benefits, for example from conservation measures designed to create or protect bird habitats, which in turn generate a range of associated benefits such as landscape enhancement, recreational opportunities, or carbon sequestration. Such benefits are not generated directly from the species that is the focus of conservation action, but would not have been generated without it. For example, special payments made to farmers to conserve Cirl Buntings (Emberiza cirlus) have had a positive economic and environmental impact, re-creating traditional landscapes and additional jobs among local farmers, farm workers and contractors (Hewitt and Robins 2001).

Non-use values are motivated by concern for the survival of wild bird species (sometimes referred to as existence values), or concern that future generations should also benefit from sharing our planet with wild birds, (sometimes referred to as bequest values). For example, a recent study by MacMillan et al. (2006) found that the general public were willing to pay almost $£ 8$ per household per year for five years, (equivalent to $£_{433,125}$ per released bird), for an release programme for Red Kites Milvus milvus, which had disappeared from much of the UK. Certain other 'pest' species such as Corvus species that predate on other, rarer species may have negative non-use values. Although there have been no studies of bird pests in this context, a recent study by Philip and MacMillan (2005) found that the public were willing to pay $£_{22}$ per household for a 5-year programme to control American Mink Mustela vison in the Western Isles which had escaped from fur farms and cause heavy losses on rare ground-nesting birds such as the Arctic Tern Sterna paradisaea.

Some of the benefits described above generate marketable goods that have considerable value and that can inject revenue into local economies as a result of direct employment of managers and wardens and/or direct payments to farmers. For example, a study by McGilvray (1996) estimated that the rights to shoot grouse could be sold for up to $£_{1}$,ooo per day and that grouse shooting generated an estimated total annual expenditure of around $£_{13} .7$ million, contributing approximately $£_{4.7}$ million in wages and salaries and supported 1,239 FTE jobs. 
Table 1. Typology of total economic value of wild birds.

\begin{tabular}{|c|c|c|c|c|c|c|}
\hline \multicolumn{5}{|l|}{$\overline{\text { USE }}$} & \multirow{2}{*}{\multicolumn{2}{|c|}{ NONUSE }} \\
\hline \multicolumn{3}{|l|}{ CONSUMPTIVE } & \multicolumn{2}{|c|}{ NON-CONSUMPTIVE } & & \\
\hline FOOD & $\begin{array}{l}\text { NON-FOOD } \\
\text { PRODUCTS }\end{array}$ & RECREATION - HUNTING & RECREATION & LEARNING & BEQUEST & EXISTENCE \\
\hline $\begin{array}{l}\text { Meat } \\
\text { Eggs } \\
\text { Guano }\end{array}$ & $\begin{array}{l}\text { Feathers } \\
\text { Goose Grease } \\
\text { Taxidermy }\end{array}$ & $\begin{array}{l}\text { Game birds } \\
\text { Hawking }\end{array}$ & $\begin{array}{l}\text { BENEFITS } \\
\text { Photography } \\
\text { Observation Hides } \\
\text { Video link }\end{array}$ & $\begin{array}{l}\text { Schools } \\
\text { Higher education } \\
\text { Direct observation }\end{array}$ & Conservation & Conservation \\
\hline Crop pest predation & & Food for target species & $\begin{array}{l}\text { ECT BENEFITS } \\
\text { Ecological Benefits }\end{array}$ & & Ecological Benefits & Ecological Benefits \\
\hline $\begin{array}{l}\text { Crop damage } \\
\text { Predation of farm } \\
\text { livestock/poultry }\end{array}$ & $\begin{array}{l}\text { Non-Food Crop damage } \\
\text { Fouling } \\
\text { Air strikes }\end{array}$ & Predation (game birds) & $\begin{array}{l}\text { COSTS } \\
\text { Pest Species }\end{array}$ & Pest Species & Pest Species? & Pest species? \\
\hline Disease transmission & Disease transmission & INDI & $\begin{array}{l}\text { IRECT COSTS } \\
\text { Ecological Costs }\end{array}$ & Ecological Costs & Ecological Costs & Ecological Costs \\
\hline
\end{tabular}


Other activities such as wildlife watching and photography cannot always be sold directly in markets or attract market prices, as they have public good characteristics of non-rivalry and nonexcludability. However, the value of activities which can be enjoyed free of charge can have a significant direct and indirect economic impact through visitor expenditure and associated downstream expenditure by tourist businesses. For example, wild-bird watching in Shetland was estimated to generate $£_{1.3}$ million per annum in gross expenditure, which in turn supported 36 FTE jobs (Rayment and Dickie 2001). Loch Garten Osprey Centre, one of the first ornithological attractions in the UK, is estimated to attract $\mathcal{E}_{1} .7$ million in expenditure and to support 69 FTE jobs (Guffogg 1996) and for Scotland as a whole, spending by visitors to Scottish wildlife sites was estimated to be in excess of $£_{30}$ million and supported 1,200 FTE jobs (Crabtree et al. 1994).

Wild birds can also generate values that form the basis for conflict. The dynamic of the conflict is often strongly influenced by bio-economics but also by socio-cultural factors and political issues. Three central issues important in understanding conflicts would appear to be: 1 ) damage intensity and population density (damage levels can be unbearable if wildlife populations are concentrated in small geographic areas such as protected areas); 2) the marked asymmetry between losers and winners - for example, the costs of wildlife are often borne by relatively few farmers, but the benefits of conservation are often shared by the global community and 3) costs usually have a tangible negative impact on income, while the benefits are more diffuse.

When considering conflicts over bird conservation from an economic perspective, it is helpful to be able to value the different costs and benefits using a common monetary scale. This common scale is necessary to allow the consistent comparison of all costs and benefits, and hence provide consistent weightings for individual costs and benefits. These positive and negative values and who they involve can then be used in a policy context to assess the economic case for government intervention to mitigate the conflict through, for example, investing in damage prevention expenditure by scaring or shooting, or by awarding compensation to groups such as farmers that are negatively affected by particular bird populations.

Valuation of costs and benefits can, nevertheless, present considerable methodological challenges. For example, identifying the damage inflicted by a species on an economic resource is not straightforward, as levels of damage can vary with factors such as population size, season and location, or can be masked by, or interact with, other environmental variables such as weather events. Where positive or negative physical impacts on a commercial product can be identified, then estimation of appropriate costs and benefits is relatively simple, as changes in market price and or quantity can be used to measure changes in value.

One major problem for conservation economics is that many of the benefits of wild birds are not captured by any type of market. For example, non-use values are pure public goods which leave no obvious or subtle behavioural trail that can provide information about their value. Hence economists are required to estimate willingness to pay (WTP) from surveys of the public who favour conservation (DETR 2001). Next we examine such a conflict from an economic perspective, using wild goose grazing in Scotland as a case study.

\section{Conflicts over wild goose conservation}

The UK is an important destination for migratory geese species in winter and early spring. The most numerous species, Pink-foot Goose Anser brachyrhynchus and Greylag Goose Anser anser, are widely dispersed in eastern areas of UK and are not endangered. In contrast, internationally protected populations of the endangered Greenland Barnacle Goose Branta leucopsis and the White-fronted Goose Anser albifrons are found in only a few locations around western coasts of the British Isles. One such place is Islay, a small island off the west coast of Scotland where over the past 30 years the number of geese over-wintering has increased dramatically due to changes in agricultural practices and productivity, and special management by the RSPB on their own reserve on Islay. 
Legislation strictly controls shooting of geese through special licenses and, although scaring is allowed, both species are highly protected by UK and European law. The rising goose population on Islay brings both benefits and costs to the island. In terms of costs, geese compete with sheep and cattle for much needed later summer and winter forage, cause damage to spring-sown cereals and grass, delay turn-out of stock, and can cause puddling and soil compaction, while scaring of geese away can use up valuable time and resources. In addition, some island residents complain about fouling of washing, and the noise generated by large numbers of geese.

On the other hand, wild geese generate a range of use and non-use benefits, both for people on Islay and for people elsewhere. Goose watching attracts tourists to the island, especially in winter when other tourists are scarce. More generally, many members of the public are supportive of bird conservation for ethical or altruistic reasons. For instance, people who are concerned about the fate of wild geese would benefit in terms of 'increased satisfaction', if they felt a conservation policy would increase the chances of conserving geese, even if these individuals never travel to Islay to go bird watching.

For the last 1o years the government has provided compensation payments to Islay farmers for goose damage, based on goose counts on individual farms undertaken by conservation staff. Currently these payments average around $£_{14}$ per goose with total expenditure almost doubling from $£_{350,000}$ in 1997 to $£ 630,000$ in 2002 (Cope et al. 2005) as goose numbers have increased. With numbers continuing to increase and the possibility of further significant increases in conservation funds the government is anxious that expenditure is targeted to maximum effect. Economic analysis is well placed to examine this issue in a rational and consistent manner by quantifying and comparing the costs and benefits of goose management in monetary terms and, by using appropriate quantitative analysis, inform policy makers regarding which species to conserve, how many to conserve, where to conserve them, and how to manage them.

\section{Costs of geese}

Although there have been a number of studies on the economic impacts of goose damage on Islay none have been based on full farm surveys (MacMillan et al. 2004). Farm surveys allow specific impacts to be investigated in depth and provide insights into the relationship between costs and goose numbers. In this study, both qualitative (focus groups) and quantitative methods (detailed on-farm interviews) were used. The sample involved 18 farms out of a total of around 50 on the island and the basis for estimating the costs of geese was individual farmers' recall of the situation the previous year. Grazing costs were obtained by asking farmers technical questions such as the number of weeks delay in turning out due to geese, and the additional costs of feeding winter rations. These data were converted into a monetary cost using standard prices for feeds.

For the effects of geese on silage, we obtained the loss of yield and the number of weeks delay in cutting, and estimated the silage losses and the value of reduced aftermath grazing using standard prices. For the effects of geese on arable, farmers estimated reduced cereal yields due to grazing of winter crops or late planting of spring cereals, and the economic consequences were calculated separately using standard prices. This approach of asking farmers questions about the physical effects of geese and then translating these into economic costs, was also used for the other anticipated costs, including the opportunity costs of a changed farm system to accommodate geese, and the costs of more frequent reseeding of grassland.

Total costs incurred across all 18 sampled farms on Islay were estimated to be $£_{206}, 000$, an average of $£_{11,500}$ per farm. Loss of early grazing was the most costly impact of geese, followed by losses to silage, including aftermath and hay. Additional reseeding costs and losses of winter grazing were also significant, but direct losses to cereal crops were relatively unimportant as Islay has little in the way of cropping. In order to estimate the goose-related costs incurred by all farms on Islay, we raised the average from our sample to all farms to give an Islay-wide estimate of $£_{560,000}$ for those costs included in the survey. This was equivalent to a weighted average 
cost of $£_{12.74}$ per goose on Islay, which is slightly lower than available compensation payments of $£_{14.33}$ per goose (Cope et al. 2005). This damage estimate is probably an underestimate as a number of farmers indicated that other costs of geese could not be easily quantified. These included reduced lambing rates, later lambing and calving, and an overall reduction in breeding livestock compared with a situation in which there were no geese.

Estimating marginal costs is normally difficult due to lack of data. However for Islay, there are good data on goose numbers for individual farms, which we used to investigate how goose damage varies with numbers of geese. The marginal cost per goose was found to be highly density-dependent and fell to less than $£_{1}$ per goose per year at very high densities (presumably because competition for limited grass is increased and consumption per goose is reduced).

\section{Non-use benefits of geese}

As shooting geese for sport is banned on Islay, the main direct use values arising from wild geese are those from goose watching, while the main non-use values stem from concern over goose conservation. While goose watching is a relatively specialised interest, non-use values were considered to be of central importance to goose conservation policy. A choice experiment approach was adopted to estimate the non-use value of three groups: the UK general population, Islay residents and Islay visitors.

Choice experiments typically involve giving respondents 6 to 8 'choice sets', each set containing two or more policy options and asking them to indicate their preferred option for each set. Each option is described in terms of 3-6 policy attributes which have several levels. These levels are varied in order to allow the researcher to infer the attributes that significantly influence choice, the implied ranking of attributes, marginal Willingness To Pay (WTP) for changes in attribute level, and WTP for a combined programme based on a combination of levels for each attribute.

The selection of attributes and their levels was discussed in focus groups involving the general public and policy makers. The final attributes and levels selected are presented in Table 2, and were considered to be both the most relevant to the goose management 'problem' and could most likely be influenced through policy design. Hypothetical costs of alternative choices are included and this variable is used to estimate marginal WTP for each level of each attribute.

The choice experiments were implemented as part of a larger questionnaire administered through in-person interviews. The choices were presented in pairs together with a 'don't know' option, and each participant was asked to complete 8 choice sets, of which an example choice set is presented in Figure 1 . Participants in the survey were selected using quota sampling to ensure representativeness in terms of age, gender and income, based on neighbourhood residence. In total 205 Islay residents (farmers and their families were excluded in case they provided biased

Table 2. Attributes and attribute levels used in the choice experiment.

\begin{tabular}{ll}
\hline Attribute & Level \\
\hline Species & Endangered species only \\
& All species \\
Location & Special reserves only \\
& All locations in Scotland \\
Method of Control & Habitat management only \\
& Shooting and habitat management \\
Population Change & Small fall $(-10 \%)$ \\
& Stay the same $(0 \%)$ \\
& Small rise $(+10 \%)$ \\
& Moderate rise $(+25 \%)$ \\
& Large rise $(+50 \%)$ \\
$£_{1} ; £_{5} ; £_{10} £_{20} £_{35} ; £ 60$ \\
\end{tabular}




\section{Please consider the following options:}

\begin{tabular}{ll}
\hline \multicolumn{1}{c}{ Policy A } & $\begin{array}{l}\text { Policy B } \\
\text { Species protected by policy: } \\
\text { Endangered species only }\end{array}$ \\
$\begin{array}{l}\text { Means of control: } \\
\text { Habitat management \& Shooting }\end{array}$ & $\begin{array}{l}\text { Means of control: } \\
\text { Habitat management \& Shooting }\end{array}$ \\
$\begin{array}{l}\text { Location: } \\
\text { Special reserves only }\end{array}$ & $\begin{array}{l}\text { Location: } \\
\text { All sites in Scotland }\end{array}$ \\
$\begin{array}{l}\text { Population change over } 10 \text { years: } \\
\text { Stay the same }\end{array}$ & $\begin{array}{l}\text { Population change over } 10 \text { years: } \\
\text { Moderate rise } \mathbf{( 2 5 \% )}\end{array}$ \\
$\begin{array}{l}\text { Price per year to you over the next ten } \\
\text { years in extra taxes: } £ 10\end{array}$ & $\begin{array}{l}\text { Price per year to you over the next ten } \\
\text { years in extra taxes: } £ 60\end{array}$
\end{tabular}

Response: I would choose Policy A

I would choose Policy B

I would choose neither Policy A nor Policy B

Figure 1. An illustrative choice card.

responses), 212 Islay visitors and 426 members of the general public were interviewed. The questionnaire consisted of four sections:

1. General questions about environmental preferences and attitudes toward wildlife conservation;

2. Description of the current situation regarding the conservation and management of wild geese and the potential role of shooting;

3. Description of the payment method (non-specific tax increase) and the contingent choices/ market; and

4. Validation questions, both socio-economic, behavioural and attitudinal.

One of the most useful outputs from a choice experiment is the calculation of the mean willingness to pay for a 'marginal' change in the level of an attribute (e.g. move from habitat management only to habitat management plus shooting). If this amount is negative, it shows how much people are willing to pay to avoid the marginal change. Table 3 gives the marginal WTP for all three sample populations.

Residents, visitors and the general public all appear to have different preferences towards goose conservation. In terms of policy, a significant positive WTP exists among both Islay

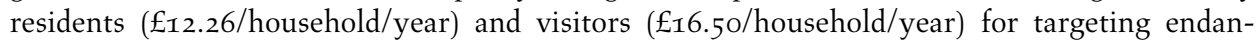
gered species only, rather than all geese. In terms of management, all three groups favoured a policy that did not involve shooting, and WTP to avoid shooting was significant in the model for both the general public ( $£ 9.23 /$ household/year) and Islay visitors ( $£ 6.74 /$ household/year). In terms of conservation, all groups favoured a policy which switched the focus from special reserves to all sites in Scotland, but WTP was only significant for visitors $(£ 6.73 /$ household/ year). 
Table 3. Monetary values for attribute levels.

\begin{tabular}{|c|c|c|c|}
\hline Attribute & General Public & Residents & Visitors \\
\hline $\begin{array}{l}\text { Species: } \\
\text { All geese species to } \\
\text { Endangered species only }\end{array}$ & $£_{0.01}$ & $£_{12.26^{*}}$ & $£_{1} 6.50^{*}$ \\
\hline $\begin{array}{l}\text { Means of control: } \\
\text { Habitat management to } \\
\text { Habitat management \& shooting }\end{array}$ & $-£ 9.23^{*}$ & $-£_{0.74}$ & $-£ 6.74^{*}$ \\
\hline $\begin{array}{l}\text { Location: } \\
\text { Special reserves only to } \\
\text { All sites in Scotland }\end{array}$ & $£_{2.35}$ & $£_{0.71}$ & $£ 6.73^{*}$ \\
\hline $\begin{array}{l}\text { Population change: } \\
\text { Low fall }(10 \%) \\
\text { Stay the same } \\
\text { Low rise }(10 \%) \\
\text { Moderate rise }(25 \%) \\
\text { High rise }(50 \%)\end{array}$ & $\begin{array}{r}-£_{4.04} \\
-£_{3.36} \\
£_{1.36} \\
£_{4.58} \\
£_{1.46}\end{array}$ & $\begin{array}{c}£_{2} .00 \\
£_{24.98^{*}} \\
-£_{1} .82 \\
£_{4.50} \\
-£_{29} .67^{*}\end{array}$ & $\begin{array}{r}-£_{7.57} \\
£ 8.21 \\
-£_{1.86} \\
£_{15.39^{*}} \\
-£_{14.18}\end{array}$ \\
\hline Number of individuals (choice sets) & $426(1,704)$ & $205(820)$ & $212(848)$ \\
\hline
\end{tabular}

* Denotes monetary value derived from significant co-efficient

The 'population change' attribute generated interesting results. Islay residents were WTP $£ 24.98 /$ household/year to avoid a 10\% fall in goose numbers but viewed a large increase in the goose population negatively (WTP $=-£_{29} .67 /$ household/year). In contrast, visitors to Islay were WTP to see goose numbers increase by $25 \%$ to the amount of $£_{15} .39 /$ household/year on average. The general public were largely indifferent to changes in population size levels. Across all three groups there is no evidence for any positive value attached to large $(50 \%)$ increases in goose populations.

\section{Discussion}

The monetized benefits and costs of bird conservation provide clear indication of how and why conservation conflicts can develop. In the case of wild geese, a conservation success story has impacted negatively on the livelihoods of farmers upon whose land conservation activities are focused. Furthermore, the costs fall on relatively few farmers on one small island and are high, averaging $£_{11,500}$ per farm per year, whereas the benefits are much more diffuse, accruing to the general public and of much lower value averaging between $£_{15-20} /$ household/year depending on scenario.

This is typical for many conservation conflicts and can preclude local solutions as beneficiaries have no economic linkage to those affected (Leader-Williams and Hutton 2005). In such a situation, government compensation is often required, especially where measures that can be taken by farmers to control damage are restricted. In the case of Islay, the government has introduced a local goose management scheme which provides farmers with compensation payments on the assumption that farmers have a right to graze their livestock on pastures that are not significantly damaged by geese. The total cost to the tax-payer of implementing local management plans including compensation payments, administration and management costs is probably now around $£_{I}$ million per annum but this research suggests that this cost is justified in the sense that the benefits of goose conservation are much larger and are widely dispersed amongst the general population. 
However, there must be a question over whether compensation payments for positive management are a sustainable solution in the long term. As previously mentioned, further significant increases in goose numbers are not desired by the public or Islay residents, and are likely to make farming on many parts of the island unviable. Indeed, this point may have been reached already on some Islay farms with very high densities of geese. Also, compensation programmes rely on political support which can be fickle, especially when priorities change or new demands on budgets arise (Wagner et al. 1997). In addition to the moral hazard problem, which refers to the possibility that farmers will seek to perpetuate or exaggerate the conflict in order to receive compensation, the goose management scheme also runs the risk of locking farmers into a relatively inflexible farming regime at a time when agricultural policy is evolving to encourage a broader economic base for farmers through diversification into tourism and other rural businesses.

Conservationists, farmers and policy makers should perhaps therefore consider other alternatives to compensation. As many have argued, conservation is best placed to contribute to sustainable management if wildlife can be seen to generate tangible economic benefits to the communities that suffer most of the costs of interacting with the species (e.g. Alpert 1996, Hutton and Leader-Williams 2003).

One option may be to sustainably use geese through a resumption of controlled sport shooting. Sport shooting, which is currently banned on Islay, could help manage the rise in goose numbers and bring significant benefits to local tourist businesses. More importantly, given the current inequitable distributions of costs and benefits from goose conservation, revenues from selling the rights to shoot could provide farmers with tangible benefits from geese. While this would be a controversial move and may jeopardise the tourist appeal of Islay to bird-watchers ${ }^{1}$, there is growing evidence around the world that hunting can be managed to protect species that were once endangered (Cowlishaw et al. 2005). One example is the critically endangered cheetah that, through the Convention on International Trade in Endangered Species of Fauna and Flora (CITES), has been the subject of limited quotas for sport hunting from privately owned land in Namibia and South Africa (Leader-Williams and Hutton 2005).

Another solution could be to encourage farmers to invest in conservation tourism by redirecting compensation payments and other financial support to agriculture on the island into an investment fund for local farmers to diversify into tourist related businesses. Recent changes to financial support mechanisms in the Common Agricultural Policy encourage such diversification and, given the long-term prospects for agriculture in such a remote area as Islay, and with depressed food prices, some form of diversification would make long term economic sense.

In a global context the arguments for a sustainable use approach are more associated with developing countries because subsidy payments to resolve wildlife conflicts are less appropriate as limited funds are available for conservation. Furthermore, the endemic problem of corruption and lack of effective institutions hinder the capacity to deliver funds to local people for conservation. In developing countries, where many people remain dependant on wild meat for sustenance and income (Botha et al. 2004), the 'sustainable use' approach is increasingly recognised as a legitimate option but in the UK it would be highly controversial due to the influence of animal rights groups and because of various socio-cultural changes that have left sport shooting somewhat marginalised in an increasingly urban-centred society. This study, for example, found that the general public and Islay visitors were prepared to pay $£_{9.23}$ and $£ 6.74$ per household per year respectively to prohibit shooting of geese on Islay.

\footnotetext{
${ }^{1}$ Goose shooting tends to generate more revenue for the local economy than watching as shooters tend to stay longer and spend more per day. A study in 1997/98 found visitor expenditure associated with goose watching in Scotland to be approximately $£_{1} .5$ million per annum, but that a further of $£_{2.1}$ million was injected by shooters (RSPB/BASC, 1998).
} 
It is interesting to note the contrast in attitudes toward geese that has occurred in recent years. In former times wild geese were an important game species, providing a source of meat ${ }^{2}$, grease for lubrication and waterproofing, and feathers for bedding and arrow flights. In Britain today, the sale of wild goose meat is no longer allowed under law, so even for more numerous and widespread species such as the Greylag, consumers have had to turn to intensively farmed poultry, and a traditional cultural link to wild goose conservation has been lost.

This paper has made a case for using economics to analyse conflict between geese and farmers. Using contemporary valuation methodology, it was possible to quantify costs and benefits of conservation and therefore to assess the impacts of those costs and benefits on different stakeholders. Of course there is much more to wildlife conservation conflicts than simply economic considerations, which tells us little about the institutional, social, historical and cultural dimensions of wildlife conflict. If conservation success stories are to avoid exacerbating or creating conflict, then economists, together with other disciplines and other stakeholder groups will need to collaborate to find new and innovative solutions that are both sustainable and equitable.

\section{References}

Alpert, P. (1996) Integrated conservation and development projects. BioScience 46 : $845-855$.

Balmford, A. and Whitten, J. (2003) Who should pay for tropical conservation, and how could the costs be met? Oryx 37: 238-250.

Botha, J., Witkowski, E. T. F., Shackleton, C. M. and Fairbanks, D. H. K. (2004) Socioeconomic differentiation in the trade of wildlife species for traditional medicines in the Lowveld, South Africa: Implications for resource management initiatives. Int. J. Sustainable Devel. and World Ecol. 11: 280-297.

Cope, D., Vickery, J. and Rowcliffe, M. (2005) From conflict to co-existence: a case study of geese and agriculture in Scotland. Pp. 176-191 in R. Woodroffe, S. Thirgood and A. Rabinowitz, eds. People and wildlife: conflict or co-existence? Cambridge, UK: Cambridge University Press.

Cowlishaw, G., Mendelson, S. and Rowcliffe, J. M. (2005) Evidence for post-depletion sustainability in a mature bushmeat market. J. Appl. Ecol. 42: 460-468.

Crabtree, J. R., Leat, P. M. K., Santarossa, J. and Thomson, K. J. (1994) The economic impact of wildlife sites in Scotland. J. Rural Stud. 10: $61-72$.

DEFRA (2005) Cost benefit analysis of badger management of bovine TB control in England. London: Department for the Environment, Food and Rural Affairs.

DETR (2001) Guidance on using stated preference techniques for the economic valuation of non-market effects. Department of the Environment, Transport and the Regions.

Guffogg, A. (1996) Operation Osprey - a case study assessing the sustainability of wildlife related tourism in Speyside. MSc Dissertation, Oxford Brookes University.

Hanley, N. D., MacMillan, D. C., Wright, R. E. and Patterson, I. (2003) Economics and the design of nature conservation policy: A case study of wild goose conservation in Scotland using choice experiments. Anim. Conserv. 6: 123-129.

Hewitt, N. and Robins, M. (2001) Cirl buntings and Countryside Stewardship farmers. Exeter, UK: RSPB.

Hutton, J. M. and Leader-Williams, N. (2003) Sustainable use and incentive-driven conservation: realigning human and conservation interests. Oryx 37: 215-226.

Leader-Williams, N. and Hutton, J. M. (2005) Does extractive use provide opportunities to offset conflicts between people and wildlife? Pp. 140-161 in R. Woodroffe, S. Thirgood and A. Rabinowitz, eds. People and wildlife: conflict or co-existence? Cambridge: Cambridge University Press.

\footnotetext{
${ }^{2}$ Goose was a popular choice for Christmas lunch in Britain until the 1950s.
} 
MacMillan, D. C., Hanley, N. and Daw, M. (2004) Costs and benefits of wild goose conservation in Scotland. Biol. Conserv. 119: 475-485.

MacMillan, D. C., Hanley, N. and Leinhoop, L. (2006) Contingent valuation: environmental polling or preference engine. Ecol. Economics 60: 299-307.

McGilvray, J. (1996) An economic study of grouse moors. Fordingbridge, UK: The Game Conservancy Scottish Research Trust.

Nyhus, P. J., Madden, F., Fischer, H. and Osofsky, S. A. (2003) Taking the bite out of wildlife damage: The challenges of wildlife compensation schemes. Conservation in Practice 4: 37-40.

Philip, L. J. and MacMillan, D. C. (2005) Exploring values, context, and perceptions in contingent valuation studies: The CV market stall technique and willingness to pay for wildlife conservation. J. Environ. Planning Manage. 48: 257-274.

Rayment, M. and Dickie, I. (2001) Conservation works for local economies in the UK. Sandy, UK: RSPB.

RSPB/BASC (1998) Geese and local economies in Scotland. A Report to the National Goose Forum. Sandy, UK: RSPB/BASC.

Thirgood, S. and Redpath, S. (2005) Hen harriers and red grouse: the ecology of a conflict. Pp. 192-208 in R. Woodroffe, S. Thirgood and A. Rabinowitz, eds. People and wildlife: conflict or co-existence? Cambridge: Cambridge University Press.

Wagner, K. K., Schmidt, R. H. and Conover, M. R. (1997) Compensation programs for wildlife damage in North America. Wildl. Soc. Bull. 25: 312-319.

\section{DOUGLAS C. MACMILLAN*, NIGEL LEADER-WILLIAMS}

Durrell Institute for Conservation \& Ecology (DICE), Marlowe Building, University of Kent, Canterbury, Kent, $\mathrm{CT}_{2}{ }_{7} \mathrm{NR}$, U.K.

* Author for correspondence; e-mail: D.C.MacMillan@kent.ac.uk 